\title{
Model Pembelajaran dalam Meningkatkan Kemampuan Membaca dan Menulis Siswa Sekolah Dasar
}

\author{
Fitriyani ${ }^{1}$, Erdi Guna Utama ${ }^{2}$ \\ STKIP Singkawang, Singkawang, Indonesia \\ fitriyaniyusufd@gmail.com ${ }^{1}$, erdi.guna.utama@gmail.com²
}

\section{Keywords :}

Model pembelajaran inkuiri, gallery walk, pemahaman

konsep

\begin{abstract}
Model pembelajaran merupakan kerangka atau konsep kegiatan dari proses pembelajaran yang melibatkan antara guru dengan siswa, siswa dengan siswa, dan siswa dengan lingkungannya. Dalam mencapai proses pembelajaran yang diharapkan maka diperlukan penguasaan kemampuan dasar yakni kemampuan membaca dan menulis siswa sekolah dasar dan model pembelajaran yang tepat. Penulisan artikel ini bertujuan untuk mengkaji dan menganalisis mengenai model pembelajaran dalam meningkatkan kemampuan membaca dan menulis siswa sekolah dasar. Model penelitian yang digunakan adalah studi literatur. Dari hasil penelaahan, hasil yang didapat menunjukkan bahwa model pembelajaran CIRC merupakan model pembelajaran yang tepat untuk meningkatkan kemampuan membaca dan menulis siswa sekolah dasar, karena menekankan kepada pemahaman, bakat dan minat siswa.
\end{abstract}

\section{INTRODUCTION}

Model pembelajaran merupakan sebuah kerangka atau perangkat yang menggambarkan prosedur untuk merancang bahan-bahan pembelajaran dan membimbing aktivitas pembelajaran yang menekankan bagaimana membantu siswa belajar mengkontruksikan pengetahuan belajar, bagaimana cara belajar, yang mencakup belajar dari sumber-sumber yang sering dianggap pasif, seperti belajar dari ceramah, film, tugas membaca, dan sebagainya. Dalam hal ini model pembelajaran dianggap sangat penting untuk menunjang keberhasilan dari proses belajar mengajar terutama pada proses meningkatkan kemampuan membaca dan menulis di sekolah dasar.

Meningkatkan berasal dari kata dasar "tingkat" memiliki makna proses, cara, dan usaha yang dikeluarkan untuk memperoleh hasil yang optimal dari kerja keras untuk meningkatkan kemampuan, skill atau keahlian. Salah satu kendala siswa sekolah dasar yakni kemampuan membaca dan menulis hal ini menyebabkan proses belajar mengajar tidak optimal. Kemampuan membaca dan menulis merupakan salah satu kemampuan dasar dari berbahasa. Bahasa adalah sebuah sarana atau alat komunikasi untuk menyampaikan informasi baik berbentuk lisan maupun tulisan. Dalam proses pembelajaran guru dan siswa melakukan interaksi dengan melakukan komunikasi agar tujuan pembelajaran yang diharapkan tercapai. 
Membaca adalah kemampuan berbahasa reseptif yang mana kegiatan berbahasa berupa proses menuliskan bahasa tulisan/lambang bunyi bahasa dan mengolah bahan bacaan secara aktif serta menanggapi dan memahami isi bahasa tulisan. Sedangkan, menulis adalah kemampuan berbahasa produktif karena menghasilkan sebuah gagasan, pikiran, dan perasaan. Pada tingkat sekolah dasar tujuan dari kemampuan membaca agar siswa memiliki kemampuan memahami dan menyuarakan tulisan dengan intonasi yang baik dan benar. Sedangkan, tujuan dari menulis adalah siswa mampu merealisasikan pokok pikiran atau gagasan yang di cerna dalam bentuk huruf, kalimat, paragraf, maupun teks tulisan.

Pada konsep belajar mengajar untuk meningkatkan kemampuan membaca dan menulis di sekolah dasar model pembelajaran dan kurikulum yang terapkan menjadi penentu pelaksanaan dan hasil pendidikan. Sistem kurikulum 2013 yang saat ini digunakan dengan sistem pembelajaran tematik terpadu menggunakan tema dan mengaitkan beberapa mata pelajaran memberikan pengalaman bermakna bagi siswa baik secara individu maupun berkelompok. Hal ini tentunya membuat kemampuan membaca dan menulis menjadi faktor utama dalam keberhasilan belajar siswa. Sehingga di butuhkan model pembelajaran yang tepat dan sesuai dengan sifat-sifat model pembelajaran terpadu sebagai berikut: 1) Model pembelajaran yang digunakan harus memiliki satu desain ilmu yang meliputi keterhubungan dan terangkai; 2) Model pembelajaran antar bidang berurutan, berjaring, keterpaduan; 3) Siswa dilibatkan langsung secara aktif dalam proses belajar mengajar yang bersifat jejaring atau network.

Model pembelajaran yang dapat meningkatkan kemampuan membaca dan menulis serta sesuai dengan sifat-sifat model pembelajaran keterpaduan diantara lain model pembelajaran Cooperative Integrated Reading and Composition (CIRC), Visual, Auditory, Read-Write, Kinesthetic (VARK) dan Picture and Picture. Ketiga model pembelajaran tersebut memiliki keunggulan-keunggulan dalam meningkatkan kemampuan membaca dan menulis siswa sekolah dasar. Model pembelajaran Cooperative Integrated Reading and Composition (CIRC) merupakan metode pembelajaran terpadu yang mana disesuaikan dengan tingkat perkembangan siswa, sesuai dengan bakat dan minat siswa, proses pembelajaran lebih bermakna sehingga meningkatkan berpikir kritis siswa, dan dapat meningkatkan motivasi belajar siswa serta interaksi sosial antara siswa dengan siswa serta siswa dengan guru. Model pembelajaran Visual, Auditory, Read-Write, Kinesthetic (VARK) merupakan model pembelajaran yang multi-sensorik yang melibatkan penglihatan, pendengaran, dan gerakan. Dalam model pembelajaran ini informasi yang ditampilkan dalam bentuk kata-kata. Dimana siswa memiliki potensi belajar membaca dan menulis dalam bentuk input dan output berbasis tesk, membaca dan menulis apa pun yang di dengarkan dan dipahami, termasuk daftar-daftar, internet, powerpoint, kamus, kutipan dan sebagainya. Sedangakan, model pembelajaran Picture and Pictire merupakan strategi pembelajaran yang menjadikan kartu bergambar sebagai perangkat utama dalam proses belajar mengajar yang mana pada model ini siswa dilatih untuk berpikir kritis dan logis, siswa berperan aktif dalam merencanakan dan pengelolaan kelas, siswa dilatih untuk melihat berbagai sudut pandang sebagai motovasi belajar siswa.

Berdasarkan hal tersebut, guru dituntut untuk melakukan inovasi dalam proses pembelajaran khususnya dalam meningkatkan kemampuan membaca dan menulis pada siswa sekolah dasar. Dari ketiga model pembelajaran diatas tentunya terdapat model pembelajaran paling tepat untuk meningkatkan kemampuan membaca dan menulis siswa tingkat sekolah dasar. Model pembelajaran Cooperative Integrated Reading and Composition (CIRC) merupakan model pembelajaran paling tepat untuk diterapkan dalam meningkatkan kemampuan membaca dan menulis siswa sekolah dasar karena termasuk kategori metode pembelajaran terpadu yang sesuai dengan konsep sistem kurikulum 2013 yang juga menerapkan keterpaduan atau keterkaitan antara tema dan mata pelajaran, menjadikan siswa sebagai pusat dari proses belajar mengajar dan menekankan pada pembelajaran bermakna. Hal ini sesuai dengan model pembelajaran Cooperative Integrated Reading and Composition (CIRC) yang mana setiap siswa bertanggung jawab terhadap tugas kelompok. Setiap anggota kelompok saling mengeluarkan ide-ide untuk memahami suatu konsep dan meyelesaikan 
tugas, sehingga terbentuk pemahaman dan pengalaman belajar yang lama.

Oleh karea itu, berdasarkan pemaparan diatas dapat diketahui bahwa model pembelajaran untuk meningkatkan kemampuan membaca dan menulis yang paling ditepat untuk diterapkan ditinjau dari sistem kurikulum dan tingkat pendidikan sekolah dasar yakni melalui penerapan model pembelajaran Cooperative Integrated Reading and Composition (CIRC).

\section{METHOD}

Artikel ini menggunakan studi literatur atau literature riview dengan menganalisis dan meninjau beberapa kajian yang berkaitan dengan topik pembahasan yaitu model pembelajaran yang dapat meningkatkan kemampuan membaca dan menulis pada siswa tingkat sekolah dasar. Sumbersumber rujukan yang menjadi pokok bahasan bersumber dari buku, jurnal artikel, dan yang lainnya.

\section{RESULTS AND DISCUSSIONS}

Penerapan model pembelajaran dalam kegiatan proses belajar mengajar sangat diperlukan untuk menunjang keberhasilan belajar siswa. Hal ini juga bertujuan untuk mempermudah guru dalam menyampaikan materi-materi pembelajaran kepada peserta didik. Penerapan model pembelajaran Cooperative Integrated Reading and Composition (CIRC) dapat mempermudah proses meningkatkan kemampuan membaca dan menulis siswa sekolah dasar. Menurut Ngalimun, 2016:240 model pembelajaran Cooperative Integrated Reading and Composition (CIRC) merupakan komposisi terpadu membaca dan menulis secara kooperatif-kelompok. Sintaksnya adalah membentuk kelompok heterogen 4 orang, guru memberikan wacana bahan bacaan sesuai dengan materi bahan ajar, siswa bekerja sama (membaca bergantian, menemukan kata kunci, memberikan tanggapan) terhadap wacana kemudian menuliskan hasil kolaboratifnya, presentasi hasil kelompok refleksi.

Menurut Saifulloh (dalam Huda, 2017: 221) Kelebihan dari model Cooperative Integrated Reading and Composition (CIRC) antara lain: 1) pengalamanan dan kegiatan belajar siswa akan selalu relevan dengan tingkat perkembangan anak; 2) kegiatan yang dipilih sesuai dengan dan bertolak dari minat dan kebutuhan siswa; 3) seluruh kegiatan belajar lebih bermakna bagi siswa sehingga hasil belajar siswa akan dapat bertahan lebih lama; 4) pembelajaran terpadu dapat menumbuh kembangkan keterampilan berpikir siswa; 5) pembelajaran terpadu menyajikan kegiatan yang bersifat pragmatis (bermanfaat) sesuai dengan permasalaan yang sering ditemui dalam lingkungan siswa; 6) pembelajaran terpadu dapat menumbuh motivasi belajar siswa kearah belajar yang dinamis, optimal, dan tepat guna; 7) pembelajaran terpadu dapat menumbuh kembangkan interaksi sosial siswa, seperti kerjasama, toleransi, komunikasi, dan respek terhadap gagasan orang lain; 8) membangkitkan motivasi belajar serta memperluas wawasan dan aspirasi guru dalam mengajar.

Langkah-langkah penerapan model pembelajaran Cooperative Integrated Reading and Composition (CIRC) menurut Steven, dkk (dalam Huda, 2017:222) sebagai berikut: 1) guru membentuk kelompokkelompok yang masing-masing terdiri dari 4 siswa; 2) guru memberikan wacana sesuai dengan topik pembelajaran; 3) siswa bekerja sama saling membacakan dan menemukan ide pokok kemudian memberikan tanggapan terhadap wacana yang ditulis pada lembar kertas; 4) siswa mempresentasikan/membacakan hasil diskusi kelompok; 5) guru memberikan penguatan (feinforcement); 6) guru dan siswa bersama-sama membuat kesimpulan.

Berdasarkan prosedur model pembelajaran Cooperative Integrated Reading and Composition (CIRC) diatas , dapat meningkatkan kemampuan membaca dan menulis siswa sekolah dasar karena Penerapan model Cooperative Integrated Reading and Composition (CIRC) memberi makna yang mendalam di dalam proses pembelajaran sehingga dapat menumbuhkan interaksi yang aktif dan positif antara siswa dengan guru, siswa dengan lingkungannya, maupun antara siswa itu sendiri. Dalam hal ini serta dalam penerapannya terdapat beberapa fase yang terdiri dari fase pengenalan konsep, fase eksplorasi dan 
aplikasi serta fase publikasi yang mendukung keberhasilan siswa dalam meningkatkan kemampuan membaca dan menulis.

Hal ini juga diperkuat dengan hasil penelitian yang dilakukan Ni Ketut Desia Tristiantari dan I Made Sumantri dengan judul penelitian "Model Pembelajaran Cooperatif Integrated Reading Composition Berpola Lesson Study Meningkatkan Keterampilan Membaca dan Menulis". Hasil penelitian menunjukkan bahwa penerapan model pembelajaran Cooperatif Integrated Reading Composition Berpola Lesson Study dapat meningkatkan kemampuan membaca dan menulis.

Dengan penerapan model pembelajaran Cooperative Integrated Reading and Composition (CIRC) siswa menjadi percaya diri, lebih aktif, dan memiliki minat yang baik dalam hal membaca dan menulis serta dalam proses belajar mengajar tercapainya tujuan-tujuan pembelajaran yang diharapkan secara optimal.

\section{CONCLUSION AND SUGGESTION}

Kemampuan membaca dan menulis merupakan kemampuan dasar siswa sekolah dasar dalam menguasai beberapa materi pembelajaran. Dimana siswa menggunakan semua proses pembelajaran diawali dengan membaca dan menulis. Penerapan model pembelajaran sangat berpengaruh terhadap tingkat keberhasilan siswa terutama dalam meningkatkan kemampuan membaca dan menulis. Guru harus sangat-sangat selektif dalam menentukan model pembelajaran yang tepat yang sesuai dengan bakat dan minat siswa.

Penerapan model pembelajaran Cooperative Integrated Reading and Composition (CIRC) merupakan model pembelajaran yang paling efektif dalam meningkatkan kemampuan menulis dan membaca siswa sekolah dasar karena dalam proses penerapannya siswa dipacu untuk aktif dengan melakukan interaksi sosial antara siswa dengan guru, siswa dengan lingkungannya, maupun antara siswa itu sendiri.

Dalam proses meningkatkan kemampuan membaca dan menulis siswa menjadi pusat dari proses pembelajaran. Secara sintaksnya penerapan model pembelajaran Cooperative Integrated Reading and Composition (CIRC) terdapat beberapa fase atau tahapan dalam meningkat kemampuan membaca dan menulis siswa sekolah dasar dari tahap pengenalan konsep yang mengacu kepada penemuanpenemuan selama ekplorasi yang di dapat dari keterangan guru, buku paket, atau media lainnya. Tahap eskplorasi dan aplikasi yang siswa memiliki peluang untuk mengungkapkan pengetahuan awalnya dengan itu siswa akan memperlihatkan reaksi atau tindakan. Tahap publikasi yang mana pada tahap ini siswa mampu mengomunikasikan hasil temuan-temuannya.

\section{REFERENCES}

Chandra, Mayarnimar, M. Habibi. 2018. Keterampilan Membaca dan Menulis Permulaan Menggunakan Model Vark untuk Siswa Sekolah Dasar. Jurnal Inovasi Pendidikan dan Pembelajaran Sekolah Dasar, 1(2).

Miftahul Huda. 2017. Model-Model Pengajaran dan Pembelajaran. Yogyakarta: Pustaka Pelajar

Ngalimun. 2016. Strategi dan Model Pembelajaran. Yogyakarta: Aswaja Pressindo.

Ni Ketut Desia Tristiantari, I Made Sumantri. 2016. Model Pembelajaran Cooperatif Integrated Reading Composition Berpola Lesson Study Meningkatkan Keterampilan Membaca dan Menulis. Jurnal Pendidikan Indonesia, 5(2), 203-211. 


\section{Journal of Educational Review and Research}

JOURNAL OF EDUCATIONAL

Putri Laura Sari. Peningkatan Kemampuan Membaca Dan Menulis Permulaan Dengan Metode Cooperative Integrated Reading And Composition Pada Mata Pelajaran Bahasa Indonesia Kelas II MIS Lamgugob Banda Aceh. Skripsi. (Banda Aceh: Fakultas Tarbiyah Dan Keguruan Universitas Islam Negeri Ar-Raniry Darussalam, 2018.s 